\title{
Study of STDs in patients attending venereal disease clinics in Khartoum, Sudan
}

\author{
O. M. A. TAHA, M. hag Ali, E. E. OMER, M. A. AhMED, AND S. A. AbBARO \\ From the Department of Dermatology and Venereology, Omdurman and Soba University Hospital, Sudan
}

SUMMARY During the period October 1976 to January 1978, 290 patients were examined for sexually transmitted diseases in three venereal disease clinics in Khartoum Province. Clinical and laboratory findings showed that nongonococcal urethritis was the commonest STD in men $(35.1 \%)$, with gonorrhoea the second commonest (25.9\%). Most of the patients with STDs were aged between 20 and 39 years. Of the infected men, $49.3 \%$ had acquired their infections from prostitutes.

\section{Introduction}

Sexually transmitted diseases (STDs) are currently the commonest contagious diseases in the world; the World Health Organisation's statistics recorded 200 million cases of gonorrhoea and 50 million cases of syphilis for the year 1972 (WHO, 1972).

Although these diseases cause much morbidity, mental ill-health, and social problems, at present they are being neglected in developing countries. There are no facilities for correct diagnosis and treatment. No adequate statistics have been collected and no previous studies carried out to determine the size of the problem (Sogbetun et al., 1977). This prompted us to report our experience of the pattern of these diseases as seen at three venereal disease clinics in Khartoum over a period of 15 months.

\section{Patients and methods}

Two hundred and ninety patients referred with a diagnosis of STD to the venereal disease clinics at Soba and Omdurman Hospitals and at the Saggana Health Centre by medical practitioners in different centres in Khartoum Province were studied over the period October 1976 to January 1978. Each clinic was held once a week.

All patients had samples of blood taken for the Venereal Disease Research Laboratory (VDRL) and fluorescent treponemal antibody-200 (FTA-200) tests. In patients with genital ulcers darkground examination of the exudate was performed. Urethral

Address for reprints: Dr M. Hag Ali, Medical Research Council, PO Box 1304, Khartoum, Sudan

Received for publication 5 December 1978 specimens were collected, and the smears were stained by Gram's method and examined microscopically for leucocytes and intracellular Gramnegative diplococci. Specimens were also plated in the clinic on chocolate agar medium and incubated immediately at $37^{\circ} \mathrm{C}$ in a candle-extinction tin. Gonococci were identified by characteristic Gramstain morphology, oxidase test, and sugar fermentation reactions.

Sabouraud's medium was inoculated for isolation of Candida albicans. Germ-tube and sugar fermentation tests were carried out for full identification of the organism.

A two-glass urine test was performed in male patients who presented with urethritis; if threads were noted a centrifuged deposit of urine was examined microscopically.

The Frei's test, lymphogranuloma venereum complement fixation test (LGVCFT), and examination of smears of ulcers for Haemophilus ducreyii were not performed for lack of facilities. The diagnosis of lymphogranuloma venereum (LGV), genital warts, molluscum contagiosum, and pediculosis pubis were made on their characteristic clinical features. Pediculosis pubis was diagnosed from the clinical features and after the louse of the Pediculus pubis had been identified under the microscope.

\section{Results}

Of the total of 290 patients referred with a diagnosis of STD to the three venereal disease clinics, 148 $(51 \%)$ did not have an STD.

Only one case of primary syphilis was detected by darkground microscopy, and this was confirmed by 
the results of the VDRL and FTA-200 tests (Table 1). Other STDs included candidosis, trichomoniasis, gonorrhoea, nongonococcal urethritis (NGU), genital warts, LGV, molluscum contagiosum, pediculosis pubis, and non-syphilitic penile ulcers (Table 1). The cases of NGU included two patients who were found to have genital candidosis.

Table 1 Analysis of the diagnoses

\begin{tabular}{|c|c|c|c|c|c|c|}
\hline \multirow[b]{2}{*}{ Diagnosis } & \multicolumn{2}{|c|}{ Men } & \multicolumn{2}{|c|}{ Women } & \multicolumn{2}{|c|}{ Total } \\
\hline & No. & $\%$ & No. & $\%$ & No. & $\%$ \\
\hline $\begin{array}{l}\text { Trichomoniasis } \\
\text { Candidosis } \\
\text { Gonorrhoea } \\
\text { Nongonococcal }\end{array}$ & $\begin{array}{r}0 \\
0 \\
20\end{array}$ & $\begin{array}{c}0 \\
0 \\
25 \cdot 9\end{array}$ & $\begin{array}{r}23 \\
43 \\
5\end{array}$ & $\begin{array}{r}32.4 \\
60.6 \\
7.0\end{array}$ & $\begin{array}{l}23 \\
43 \\
25\end{array}$ & $\begin{array}{l}15 \cdot 5 \\
29 \cdot 1 \\
16 \cdot 9\end{array}$ \\
\hline $\begin{array}{l}\text { urethritis } \\
\text { Syphilitic penile }\end{array}$ & 27 & $35 \cdot 1$ & 0 & 0 & 27 & $18 \cdot 1$ \\
\hline $\begin{array}{l}\text { ulcers } \\
\text { Non-syphilitic }\end{array}$ & 1 & $1 \cdot 3$ & 0 & 0 & 1 & 0.7 \\
\hline $\begin{array}{l}\text { penile ulcers } \\
\text { Warts } \\
\text { Lymphogranuloma }\end{array}$ & $\begin{array}{r}18 \\
4\end{array}$ & $\begin{array}{r}23 \cdot 4 \\
5 \cdot 2\end{array}$ & $\begin{array}{l}0 \\
0\end{array}$ & $\begin{array}{l}0 \\
0\end{array}$ & $\begin{array}{r}18 \\
4\end{array}$ & $\begin{array}{r}12 \cdot 2 \\
2 \cdot 7\end{array}$ \\
\hline $\begin{array}{l}\text { venereum } \\
\text { Molluscum }\end{array}$ & 4 & $5 \cdot 2$ & 0 & 0 & 4 & $2 \cdot 7$ \\
\hline $\begin{array}{l}\text { contagiosum } \\
\text { Pediculosis pubis } \\
\text { Total }\end{array}$ & $\begin{array}{r}2 \\
1 \\
77\end{array}$ & $\begin{array}{l}2 \cdot 6 \\
1 \cdot 3\end{array}$ & $\begin{array}{r}0 \\
0 \\
71\end{array}$ & $\begin{array}{r}0 \\
0 \\
100\end{array}$ & $\begin{array}{r}2 \\
1 \\
148\end{array}$ & $\begin{array}{r}1 \cdot 3 \\
0 \cdot 7 \\
100\end{array}$ \\
\hline
\end{tabular}

The age range of all the patients according to diagnosis is shown in Table 2. Most of the male patients had sexual contact with prostitutes and girlfriends (Table 3).

\section{Discussion}

As in other parts of the world (Willcox, 1975; Sogbetun, 1977), we found that NGU was the most common STD among male patients $(35.1 \%)$ followed by gonococcal urethritis (25.9\%). Syphilis accounted for only $1.3 \%$ of patients. This low incidence of syphilis may be because patients with genital ulcers fear syphilis and seek antisyphilitic treatment at a very early stage at the nearest pharmacy, or from
Table 3 Sexual contacts of male patients

\begin{tabular}{lcc}
\hline Contact & No. & $\%$ \\
\hline Prostitute & 38 & 49.3 \\
Girlfriend* & 5 & 6.6 \\
Wife & 0 & 0 \\
Not admitted & 34 & 44.1 \\
Total & 77 & 100 \\
\hline
\end{tabular}

* Regular sexual relationship for at least three months but without legal marriage or dependent on financial payments or other gifts.

hospital orderlies, or from the doctor before reporting to the venereal disease clinic.

Candidosis was the commonest STD among female patients $(60.6 \%)$, with most cases in the age group 20-29 years. Trichomoniasis was the second commonest condition, and again most cases were in the age group 20-29 years.

Most of our patients $(86.5 \%)$ were aged between 20 and 39 years, which coincides with the period of greatest sexual activity and follows the same worldwide pattern observed by Idsoe et al. (1973).

Although prostitution is prohibited in Khartoum, $49.3 \%$ of the male patients were infected by prostitutes. This figure reflects the degree of inefficiency in enforcing this legislation. On the other hand, $44.1 \%$ of the male patients did not admit the source of their infection; they denied having any sexual intercourse and stated that they developed the STD after a nightmare. This illustrates the patients' ignorance concerning the transmission of these diseases, their lack of health education, and the difficulty to be expected when planning contacttracing in the future. Contact-tracing is not carried out at present because of lack of facilities, lack of personnel, and other social factors.

We acknowledge the co-operation and technical assistance of Mir A. Darrag and other workers in the Department of Medical Microbiology, Faculty of Medicine, Khartoum.

Table 2 Relationship of age to incidence of STDs

\begin{tabular}{|c|c|c|c|c|c|c|c|}
\hline \multirow[b]{2}{*}{ Diagnosis } & \multicolumn{7}{|c|}{ Age group (years) } \\
\hline & $15-19$ & $20-29$ & $30-39$ & $40-49$ & $\begin{array}{l}50 \text { and } \\
\text { over }\end{array}$ & $\begin{array}{l}\text { Not } \\
\text { certain }\end{array}$ & Total \\
\hline $\begin{array}{l}\text { Trichomoniasis } \\
\text { Candidosis } \\
\text { Gonorrhoea } \\
\text { Nongonococcal } \\
\text { urethritis }\end{array}$ & $\begin{array}{l}1 \\
1 \\
2 \\
0\end{array}$ & $\begin{array}{l}10 \\
20 \\
17 \\
21\end{array}$ & $\begin{array}{r}8 \\
14 \\
6 \\
6\end{array}$ & $\begin{array}{l}2 \\
6 \\
0 \\
0\end{array}$ & $\begin{array}{l}1 \\
0 \\
0 \\
0\end{array}$ & $\begin{array}{l}1 \\
2 \\
0 \\
0\end{array}$ & $\begin{array}{l}23 \\
43 \\
25 \\
27\end{array}$ \\
\hline $\begin{array}{l}\text { Penile ulcers } \\
\text { Genital warts } \\
\text { Molluscum } \\
\text { contagiosum }\end{array}$ & $\begin{array}{l}1 \\
0 \\
0\end{array}$ & $\begin{array}{r}11 \\
4 \\
1\end{array}$ & $\begin{array}{l}6 \\
0 \\
1\end{array}$ & $\begin{array}{l}1 \\
0 \\
0\end{array}$ & $\begin{array}{l}0 \\
0 \\
0\end{array}$ & $\begin{array}{l}0 \\
0 \\
0\end{array}$ & $\begin{array}{r}19 \\
4 \\
2\end{array}$ \\
\hline $\begin{array}{l}\text { Pediculosis } \\
\text { pubis }\end{array}$ & 1 & 0 & 0 & 0 & 0 & 0 & 1 \\
\hline $\begin{array}{l}\text { Lymphogranuloma } \\
\text { venereum }\end{array}$ & 1 & 2 & 1 & 0 & 0 & 0 & 4 \\
\hline Total $(\%)$ & $7(4 \cdot 7)$ & $86(58 \cdot 1)$ & $42(28 \cdot 4)$ & $9(6 \cdot 1)$ & $1(0.7)$ & $3(2 \cdot 0)$ & $148(100)$ \\
\hline
\end{tabular}




\section{References}

Idsoe, O., Kiraly, K., and Causse, G. (1973). Venereal diseases and treponematoses: the epidemiological situation and WHO's control programme. Chronical of the World Health Organisation, $27,410-417$.

Sogbetun, A. O., Alausa, K. O., and Osoba, A. O. (1977). Sexually transmitted diseases in Ibadan, Nigeria. British Journal of Venereal Diseases, 53, 155-160.
Willcox, R. R. (1975). Importance of the so-called 'other' sexually transmitted diseases. British Journal of Venereal Diseases, 51, 221-226.

World Health Organisation (1972). Annual Report of the Director General. WHO: Geneva. 